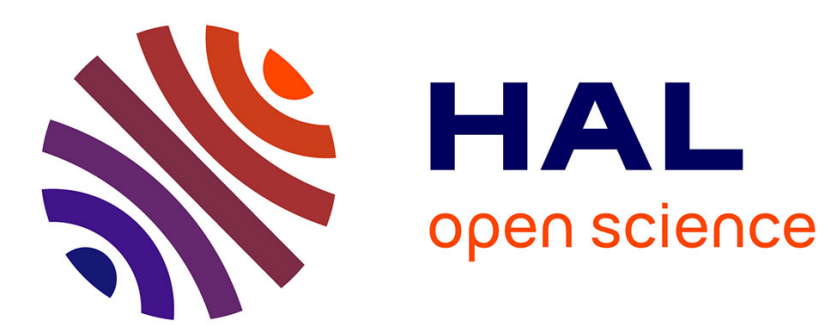

\title{
An artificial sodium ion channel from calix[4]arene in the 1,3-alternate conformation
}

Peter J. Cragg, Olasupo Lawal, Khayzuran Iqbal, Ali Mohamadi, Parichehr Razavi, Howard Dodd, Marcus Allen, Samreen Siddiqui, Flavia Fucassi

\section{- To cite this version:}

Peter J. Cragg, Olasupo Lawal, Khayzuran Iqbal, Ali Mohamadi, Parichehr Razavi, et al.. An artificial sodium ion channel from calix[4]arene in the 1,3-alternate conformation. Supramolecular Chemistry, 2009, 21 (01-02), pp.55-60. 10.1080/10610270802528307 . hal-00513548

\section{HAL Id: hal-00513548 \\ https://hal.science/hal-00513548}

Submitted on 1 Sep 2010

HAL is a multi-disciplinary open access archive for the deposit and dissemination of scientific research documents, whether they are published or not. The documents may come from teaching and research institutions in France or abroad, or from public or private research centers.
L'archive ouverte pluridisciplinaire HAL, est destinée au dépôt et à la diffusion de documents scientifiques de niveau recherche, publiés ou non, émanant des établissements d'enseignement et de recherche français ou étrangers, des laboratoires publics ou privés. 


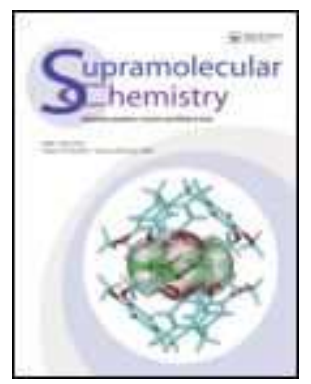

\section{An artificial sodium ion channel from calix [4]arene in the 1,3-alternate conformation}

\begin{tabular}{|c|c|}
\hline Journal: & Supramolecular Chemistry \\
\hline Manuscript ID: & GSCH-2008-0074.R1 \\
\hline Manuscript Type: & Special Issue Paper \\
\hline $\begin{array}{r}\text { Date Submitted by the } \\
\text { Author: }\end{array}$ & $01-$ Oct-2008 \\
\hline Complete List of Authors: & $\begin{array}{l}\text { Cragg, Peter; University of Brighton } \\
\text { Lawal, Olasupo; University of Brighton, School of Pharmacy and } \\
\text { Biomolecular Sciences } \\
\text { Iqbal, Khayzuran; University of brighton, School of Pharmacy and } \\
\text { Biomolecular Sciences; University of Brighton, School of Pharmacy } \\
\text { and Biomolecular Sciences } \\
\text { Mohamadi, Ali; University of Brighton, School of Pharmacy and } \\
\text { Biomolecular Sciences } \\
\text { Razavi, Parichehr; University of Brighton, School of Pharmacy and } \\
\text { Biomolecular Sciences } \\
\text { Dodd, Howard; University of Brighton, School of Pharmacy and } \\
\text { Biomolecular Sciences } \\
\text { Allen, Marcus; University of Brighton, School of Pharmacy and } \\
\text { Biomolecular Sciences } \\
\text { Siddiqui, Samreen; University of Brighton, School of Pharmacy and } \\
\text { Biomolecular Sciences } \\
\text { Fucassi, Flavia; University of Brighton, School of Pharmacy and } \\
\text { Biomolecular Sciences }\end{array}$ \\
\hline Keywords: & $\begin{array}{l}\text { Calixarenes, Artificial ion channels, Electrophysiology, Ion } \\
\text { transport, Polyethers }\end{array}$ \\
\hline \multicolumn{2}{|c|}{$\begin{array}{l}\text { Note: The following files were submitted by the author for peer review, but cannot be converted } \\
\text { to PDF. You must view these files (e.g. movies) online. }\end{array}$} \\
\hline PJC Scheme 1.cdx & \\
\hline
\end{tabular}




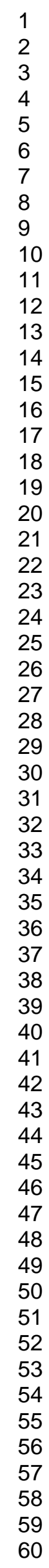

5) ScholaroNE"

25

26

27

29

30

31

33

34

35

36

37

39

40

41

42

44

45

46

47

48

49

50

52

53

54

55

57

58

59

60

URL: http:/mc.manuscriptcentral.com/tandf/gsch Email: suprachem@mail.cm.utexas.edu 


\section{Graphical Abstract}

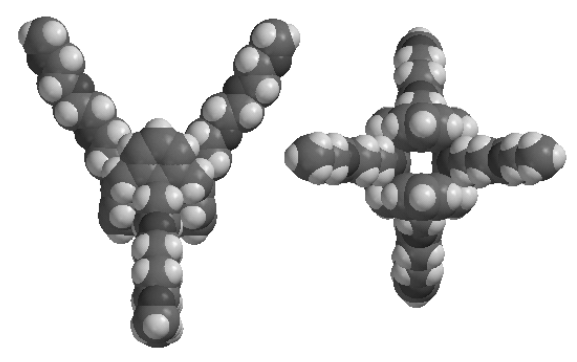

O. Lawal, K. S. J. Iqbal, A. Mohamadi, P. Razavi, H. T. Dodd, M. C. Allen, S. Siddiqui, F. Fucassi and P. J. Cragg

An Artificial Sodium Ion Channel from Calix[4]arene in the 1,3-Alternate Conformation 


\title{
An artificial sodium ion channel from calix[4]arene in the
}

\author{
1,3-alternate conformation \\ OLASUPO LAWAL, KHAYZURAN S. J. IQBAL, ALI MOHAMADI, \\ PARICHEHR RAZAVI, HOWARD T. DODD, MARCUS C. ALLEN, SAMREEN \\ SIDDIQUI, FLAVIA FUCASSI and PETER J. CRAGG* \\ School of Pharmacy and Biomolecular Sciences, University of Brighton, Cockcroft \\ Building, Moulsecoomb, Brighton BN2 4GJ, UK
}

\begin{abstract}
The synthesis of a calix[4]arene with pendent polyether substituents is described. The compound was shown by NMR to bind $\mathrm{Na}^{+}$when in the 1,3-alternate conformation and computational simulations suggest metal binding within the calixarene annulus. ${ }^{1} \mathrm{H}$ NMR indicated that the complexed cation attracts water and the formation of a stable dihydrate was also indicated by in silico methods. Lipid bilayer experiments confirmed that the 1,3-alt calixarene functions as an artificial transmembrane ion in the presence of $\mathrm{Na}^{+}$but not $\mathrm{K}^{+}$.
\end{abstract}

Keywords: Calixarenes; Polyethers; Artificial ion channels; Electrophysiology; Ion transport

\footnotetext{
*Corresponding author. Tel.: +44 1273 642037. Fax: +44 1273 679333. E-mail: P.J.Cragg@bton.ac.uk.
} 


\section{INTRODUCTION}

From the earliest days of supramolecular chemistry researchers have exploited the biomimetic potential of macrocycles and related molecules. Similarities between crown ethers and the ionophores valinomycin and nonactin helped to explain the ion transporting ability of the former [1]. Likewise enterobactin, a highly selective bacterial siderophore that targets $\mathrm{Fe}^{\mathrm{III}}$ in aqueous solution with a binding constant approaching $10^{50}$, inspired a range of tripodal chelating agents [2]. On a broader front, calixarenes, cyclam derivatives and podands have all been considered as frameworks from which artificial metalloenzymes could be constructed [3].

Many analogues of naturally occurring macrocycles succeed because they bind guests strongly with high specificity, however, it is often just as important to facilitate highly specific binding that is environmentally reversible. In Nature examples can be found in transmembrane ion channels $[4,5,6]$. These are generally composed of large proteins having an affinity for cell surfaces with regions that can pass through the cellular phospholipid bilayer. The transmembrane region of the protein (or aggregation of proteins) forms a pore, through which ions travel, which must be continuous through the bilayer if ions are to flow continuously. This necessitates a concerted structure between 3 and $6 \mathrm{~nm}$. The ion transport that results is controlled through two main mechanisms: filtering and gating.

Currently much of our detailed understanding ion channel protein behaviour relies on electrophysiological studies and the few high resolution crystal structures that are available. A vast majority of these are of proteins selective for simple cations [7] such 
as the $\mathrm{K}^{+}$channels $\mathrm{KcsA}$ [8] and MthK [9], the $\mathrm{Mg}^{2+}$ transporter MgtE [10], $\mathrm{Na}^{+} / \mathrm{K}^{+}$ channels [11,12], and an acid sensing ion channel, $\triangle \mathrm{ASIC} 1$ [13]. These structures in turn often act as models for other, less well characterized, channel proteins such as the $\mathrm{K}^{+}$selective region of the protein product of the hERG (human ether-á-go-go) gene [14]. Despite the wealth of information concerning the physiological activity of natural transmembrane proteins there are extensive deficiencies our detailed knowledge of ion transport mechanisms. For example, structural and dynamic evidence from the voltage-gated $\mathrm{K}^{+}$channel KcsA indicates that as hydrated ions approach the entrance to the pore, which often resembles a funnel, they are stripped of their solvent shell as they reach a constrictive filter $[8,15]$, yet whether this is a general principle remains unknown. The same deficiencies exist in our knowledge of the channel gating processes which control the flow of ions response to a range of external stimuli.

Synthetic ion channel models allow individual aspects of transmembrane transport to be probed, in particular the structural changes that can alter specificity or transport rate. Artificial analogues of cation channels based on crown ethers first started appearing in the 1980s [16] and have since been refined to include membranespanning substituents with high specificity $[17,18]$ and even voltage-dependent gating [19]. Rigid macrocycles have also been employed in cation channel mimetic compounds. Resorcin[4]arenes with undecyl and heptadecyl substituents conduct both $\mathrm{Na}^{+}$and $\mathrm{K}^{+}$, with selectivity for $\mathrm{K}^{+}$over $\mathrm{Na}^{+}$by a factor of three, but only for derivatives with the longer substituents [20]. Similar results were reported for other resorcin[4]arenes [21] but calixarenes, in particular calix[4]arene, have latterly been seen as potential ion selective filters around which ionophore or channel frameworks 
can be constructed $[22,23]$. Calix[4]arene-cholic acid conjugates have been shown to transport $\mathrm{Na}^{+}$across vesicle membranes with the rate constant for the 1,3-alt conformer an order of magnitude higher than the cone [24]. This agrees with other examples that suggest 1,3-alt calix[4]arenes exhibit enhanced ionophoricity [25]. In this work we report on the synthesis and behaviour of an amphiphilic 1,3-alt calix[4]arene derivative designed to probe the influence of conformation on metal ion selectivity and transmembrane transport.

\section{EXPERIMENTAL}

Unless otherwise stated, all materials and solvents are from Sigma-Aldrich (Gillingham, Dorset, UK). NMR spectra were recorded on a Bruker AM-360 instrument at 360 and $90 \mathrm{MHz}$ for ${ }^{1} \mathrm{H}$ and ${ }^{13} \mathrm{C}$ respectively. Chemical shifts were referenced to tetramethylsilane (TMS). Elemental analysis of polyether-containing compounds is often inconsistent due to variable levels and composition of included solvent. For this reason high resolution electrospray ionization mass spectrometry was used to determine the compounds' identities as the technique is known to be a good method of analysis for supramolecular complexes [26]. HRMS were recorded on a Bruker micrOTOF instrument operating in the positive mode. Calix[4]arene (1) was prepared from 4-t-butylcalix[4]arene according to the literature [27].

\section{Triethylene glycol tosylate, monomethyl ether (2)}

Triethylene glycol monomethyl ether $(16.1 \mathrm{ml}, 16.4 \mathrm{~g}, 0.1 \mathrm{~mol})$ was dissolved in a mixture of tetrahydrofuran $(50 \mathrm{ml})$ and aqueous sodium hydroxide $(5.7 \mathrm{~g}, 0.14 \mathrm{~mol}$ in $30 \mathrm{ml} \mathrm{H}_{2} \mathrm{O}$ ) and stirred in an ice bath until the solution temperature fell below $5^{\circ} \mathrm{C} . \mathrm{A}$ 
solution of $p$-toluenesufonyl chloride $(20.7 \mathrm{~g}, 0.11 \mathrm{~mol})$ in tetrahydrofuran $(30 \mathrm{ml})$ was added to the stirred solution at a rate that kept the temperature below $5^{\circ} \mathrm{C}$. Once the addition was complete, the solution was left to stir for a further $1 \mathrm{~h}$ below $5^{\circ} \mathrm{C}$, poured onto iced water $(75 \mathrm{ml}$ water, $75 \mathrm{~g}$ ice) and stirred until all the ice melted. Most of the tetrahydrofuran was removed by rotary evaporation and the product extracted into dichloromethane $(3 \times 30 \mathrm{ml})$. The organic extract was dried over calcium chloride, filtered and the solvent removed by rotary evaporation. Triethylene glycol tosylate, monomethyl ether, 2, was obtained as a colourless oil. Yield: $27 \mathrm{~g}$ $(87 \%) ;{ }^{1} \mathrm{H} \mathrm{NMR}\left(\mathrm{CDCl}_{3}\right) \delta: 7.80(\mathrm{~d}, J=8.6,2 \mathrm{H} \mathrm{ArH}), 7.35(\mathrm{~d}, J=8.6,2 \mathrm{H} \mathrm{ArH}), 4.16$ (t, $\left.2 \mathrm{H},-\mathrm{CH}_{2} \mathrm{OTs}\right), 3.50-3.75\left(\mathrm{~m}, 10 \mathrm{H},-\mathrm{CH}_{2} \mathrm{CH}_{2} \mathrm{O}-\right), 3.39$ (s, 3H, $\left.-\mathrm{OCH}_{3}\right), 2.45(\mathrm{~s}, 3 \mathrm{H}$, $\mathrm{TsCH} 3) ;{ }^{13} \mathrm{C} \mathrm{NMR}\left(\mathrm{CDCl}_{3}\right) \delta: 144.8,132.9,129.5,127.8,72.4,71.8,71.0,70.6,70.1$, 69.7, 58.8, 21.5; ESI HRMS m/z found: 341.1056, calculated: $341.1035[\mathrm{M}+\mathrm{Na}]^{+}$.

\section{Triethylene glycol iodide, monomethyl ether (3) [28]}

Triethylene glycol tosylate, monomethyl ether, 2, (10 g, $0.03 \mathrm{~mol})$ was dissolved in acetone (125 ml). Potassium iodide (25 g [5 equiv.]) was added and refluxed overnight. The solution was cooled to room temperature and filtered to remove inorganic salts. The solvent was removed under reduced pressure and the residue dissolved in a mixture of ethyl acetate $(75 \mathrm{ml})$ and distilled water $(75 \mathrm{ml})$. The mixture was separated and the ethyl acetate phase washed with water $(30 \mathrm{ml})$ then saturated sodium thiosulfate $(50 \mathrm{ml})$. The organic phase was dried over magnesium sulfate, filtered and solvent removed to give triethylene glycol iodide, monomethyl ether, 3, as a colourless oil. Yield: $5.2 \mathrm{~g}(61 \%)$; ${ }^{1} \mathrm{H}$ NMR $\left(\mathrm{CDCl}_{3}\right) \delta: 3.76(\mathrm{t}, 2 \mathrm{H}$, $\mathrm{CH}_{2} \mathrm{OCH}_{3}$ ), 3.65-3.70 (m, 6H, $\left.-\mathrm{CH}_{2} \mathrm{CH}_{2} \mathrm{O}-\right)$, 3.54-3.60 (m, 2H, $\left.-\mathrm{OCH}_{2} \mathrm{CH}_{2} \mathrm{I}\right), 3.39$ (s, 
$\left.3 \mathrm{H},-\mathrm{OCH}_{3}\right), 3.26\left(\mathrm{t}, 2 \mathrm{H},-\mathrm{OCH}_{2} \mathrm{CH}_{2} \mathrm{I}\right) ;{ }^{13} \mathrm{C} \mathrm{NMR}\left(\mathrm{CDCl}_{3}\right) \delta: 72.5,71.6,70.5$ (x 2), 70.1, 59.0, 3.3; ESI HRMS m/z found: 296.9998, calculated: $296.9964[\mathrm{M}+\mathrm{Na}]^{+}$.

\section{Tetrakis(triethylene glycol monomethyl ether) calix[4]arene, 1,3-alternate conformer (1,3-alt 4)}

Following the method of Verboom et al. [29] a suspension of calix[4]arene, 1, (0.50 $\mathrm{g}, 1.15 \mathrm{mmol}$ [98\%]), anhydrous caesium carbonate $(0.32 \mathrm{~g}, 2.3 \mathrm{mmol})$ and iodotriethylene glycol monomethyl ether, 3, (1.26 g, $4.6 \mathrm{mmol})$ was refluxed in anhydrous acetonitrile $(100 \mathrm{ml})$ under nitrogen for 7 days. After cooling to room temperature the solvent was removed under reduced pressure and the solids taken up in dichloromethane $(30 \mathrm{ml})$. The suspension was washed with $1 \mathrm{M}$ hydrochloric acid $(2 \times 10 \mathrm{ml})$ and brine $(10 \mathrm{ml})$, the organic phase separated and solvent removed under reduced pressure. The crude material was subjected to flash chromatography on silica $(\mathrm{BDH})$, eluting with ethanol, and fractions with an $\mathrm{R}_{\mathrm{f}}$ of 0.84 were combined. Removal of solvent left a viscous residue that slowly solidified. The residue was dissolved in hot diethyl ether and left in a freezer overnight. A beige powder, isolated by filtration, was shown to be tetrakis(triethylene glycol monomethyl ether) calix[4]arene in the 1,3-alternate conformation (1,3-alt 4). Solvent was removed from the filtrate to yield a mobile oil containing an intractable mixture of mono-, tri- and tetrasubstituted calix[4]arenes in the cone conformer. Yield of 1,3-alt 4: $139 \mathrm{mg}$ (12\%); m.p.: 80.3-80.5 ${ }^{\circ}$; ${ }^{1} \mathrm{H}$ NMR $\left(\mathrm{CDCl}_{3}\right) \delta: 7.05(\mathrm{~d}, J=7.56,8 \mathrm{H}, \mathrm{Ar} H), 6.62(\mathrm{t}, J$ $=7.56,4 \mathrm{H}, \mathrm{ArH}), 3.85\left(\mathrm{~m}, 8 \mathrm{H},-\mathrm{CH}_{2} \mathrm{OAr}\right), 3.75\left(\mathrm{~s}, 8 \mathrm{H}, \mathrm{ArCH}_{2} \mathrm{Ar}\right), 3.73-3.67(\mathrm{~m}$, $\left.20 \mathrm{H},-\mathrm{CH}_{2} \mathrm{CH}_{2} \mathrm{O}-\right), 3.60-3.54\left(\mathrm{~m}, 2 \mathrm{OH},-\mathrm{CH}_{2} \mathrm{CH}_{2} \mathrm{O}-\right), 3.38\left(\mathrm{~s}, 12 \mathrm{H},-\mathrm{OCH}_{3}\right) ;{ }^{13} \mathrm{C} \mathrm{NMR}$ $\left(\mathrm{CDCl}_{3}\right) \delta: 155.7,133.5,129.9,121.7,72.0,71.2,70.8,70.7,70.6,70.4,59.1,35.0$ 
ESI HRMS m/z found: 527.2638, 1031.4727, calculated: $527.2621[\mathrm{M}+2 \mathrm{Na}]^{2+}$, $1031.5344[\mathrm{M}+\mathrm{Na}]^{+}$.

\section{NMR binding studies}

Compound 1,3-alt 4 was dissolved in $\mathrm{CDCl}_{3}$ and the ${ }^{1} \mathrm{H}$ and ${ }^{13} \mathrm{C}$ spectra recorded at $25^{\circ} \mathrm{C}$. An excess of solid $\mathrm{NaPF}_{6}$ was added and the spectra recorded again after 2 min, $27 \mathrm{~min}, 87 \mathrm{~min}$ and $18.5 \mathrm{~h}$. An analogous experiment was undertaken with $\mathrm{NH}_{4} \mathrm{PF}_{6}$.

\section{Molecular modelling}

Cone and1,3-alt conformers of $\mathbf{4}$ were drawn with ChemDraw and exported into Spartan '06 [30]. Full geometry optimization was undertaken using restricted HF/PM3 methods from energy minimized structures initially calculated using the MMFF94 molecular mechanics forcefield. The $\mathrm{Na}^{+}$complex of 1,3-alt 4 and its dihydrate were constructed using options from the Build menu. For the initial dihydrate structures two water molecules were introduced in close proximity to the RHF/PM3 geometry optimized metal complexes prior to further geometric refinement by the RHF/PM3 method. In general 450 to 500 iterative cycles were required to optimize the $\mathrm{Na}^{+} \cdot 1,3$-alt $4 \mathrm{RHF} / \mathrm{PM} 3$ model geometry with a further 130 cycles to optimize that of the dihydrate.

\section{Planar bilayer experiments}

The general method used is described elsewhere [31]. Pure synthetic lipids (Avanti Polar Lipids, Birmingham, AL USA) were dispersed in chloroform and stored at $70^{\circ} \mathrm{C}$ under nitrogen. Lipid bilayers were formed from a dispersion of $15 \mathrm{mg} / \mathrm{ml} 1$ palmitoyl-2-oleoyl phosphatidylethanolamine (POPE) and $15 \mathrm{mg} / \mathrm{ml}$ 1-palmitoyl-2- 
oleoyl phosphatidylserine (POPS) in $n$-decane, which was drawn across a $0.25 \mathrm{~mm}$ diameter hole in a polystyrene cup separating two solution filled chambers, designated cis and trans. The cis chamber (to which the calixarene was added) was held at ground, and the trans chamber was clamped at $-50 \mathrm{mV}$ using a BLM-120 patch clamp amplifier (Bio-Logic) equipped with a 10GB (10 G $\Omega$ ) bilayer headstage (Warner Instruments). The sign of the membrane potential refers to the trans chamber, and currents are defined as positive when cations flow from trans to cis. Transmembrane currents were low pass filtered at $300 \mathrm{~Hz}$ (4 pole Bessel) digitized at $10 \mathrm{kHz}$ and recorded directly to disk via a CED Micro 1401 Mark II AD interface. Membrane capacitance was measured by differentiating a triangular wave input of 0.2 $\mathrm{kHz}$. Only bilayers that had a resting conductance of less than $10 \mathrm{pS}$ and an initial capacitance of at least $150 \mathrm{pF}$ were used. For cation transport studies bilayers were bathed in symmetrical Ringer's solutions containing either $150 \mathrm{mM} \mathrm{NaCl}$ or $150 \mathrm{mM}$ $\mathrm{KCl} ; 10 \mathrm{mM}$ HEPES; $1 \mathrm{mM}$ EGTA; $1.05 \mathrm{mM} \mathrm{CaCl} ; 1 \mathrm{mM} \mathrm{MgCl}_{2} ; 50 \mu \mathrm{M}$ free calcium. All recordings were made at room temperature and analyzed offline using WinEDR v2.3.9 software (Strathclyde electrophysiological software).

\section{RESULTS AND DISCUSSION}

We have previously reported model compounds for a sodium cation filter [32] and transmembrane channel [33] that have threefold symmetry. Both encapsulate $\mathrm{Na}^{+}$ within a cavity defined by six oxygen atoms, presumably due to a preference for an octahedral coordination environment, and cations in the filter model are additionally linked by coordinated water. Interestingly, this trimeric motif, unique so far in ion channel architecture, has recently been found in the high resolution structure of an $\mathrm{H}^{+}$- 
activated ion channel [13]. In the case of $\mathrm{K}^{+}$, both binding [34] and transport [21] appear to require ligands with eight binding sites in the cubic arrangement also found in the filter region of the $\mathrm{K}^{+}$-selective transmembrane protein KcsA [8]. To date, well known examples of metal transporting calix[4]arenes and related resorcin[4]arenes are almost exclusively restricted to $\mathrm{K}^{+}$.

Calixarene 1,3-alt 4 was originally prepared through reaction of the tosylated polyether, 2, with de-t-butylated calix[4]arene, 1, using the appropriate metal carbonate; however the easily synthesised iodo derivative, $\mathbf{3}$, was found to give a cleaner reaction (Scheme 1). Initially we attempted to synthesize both cone $\mathbf{4}$ and 1,3alt $\mathbf{4}$ using potassium and caesium carbonate, respectively. Workup of the reaction mixtures isolated solid 1,3-alt $\mathbf{4}$ in both cases. In addition to mass spectral evidence, the NMR spectra showed a singlet at $3.75 \mathrm{ppm}$ in the ${ }^{1} \mathrm{H}$ spectrum which correlated with a peak at $35.0 \mathrm{ppm}$ in the ${ }^{13} \mathrm{C}$ spectrum in agreement with literature values for 1,3-alt calixarenes [35]. Mass spectra of the remaining oily residues confirmed them to be mixtures of mono-, tri- and tetrasubstituted calix[4]arenes with the corresponding $\mathrm{m} / \mathrm{z}$ values of 593.2, 885.4 and 1031.5 a.u for their sodium salts. NMR confirmed that these compounds were in the cone conformer: a pair of doublets at 4.45 and $4.25 \mathrm{ppm}$ in the ${ }^{1} \mathrm{H}$ spectrum correlated with a peak at $31.9 \mathrm{ppm}$ in the ${ }^{13} \mathrm{C}$ spectrum. Given the difficulty in separating the cone components attention was focused on 1,3-alt 4.

To our surprise $\mathrm{Na}^{+}$, but not $\mathrm{K}^{+}$, inclusion in 1,3-alt $\mathbf{4}$ was inferred from changes in the ${ }^{1} \mathrm{H}$ and ${ }^{13} \mathrm{C}$ NMR spectra (Fig. 1 and Table S1 in the Supporting Information). The most significant feature of the ${ }^{1} \mathrm{H}$ spectrum was the deshielding of the aromatic 
protons by 0.16 and $0.05 \mathrm{ppm}$. This effect was mirrored in the ${ }^{13} \mathrm{C}$ spectrum where the associated carbons moved by 1.17 and $0.35 \mathrm{ppm}$. The shielding was increased for the phenolic carbon $(-0.34 \mathrm{ppm})$ together with the protons on the methylene bridge $(-0.03$ ppm) and those of the first carbon of the lower rim substituents. The methylene bridge gave rise to a singlet at $3.75 \mathrm{ppm}$ in the absence of $\mathrm{Na}^{+}$. Over the course of an $18 \mathrm{~h}$ experiment the peak was initially shielded $(-0.11 \mathrm{ppm})$ before coalescing with ethyleneoxy resonances at $3.71 \mathrm{ppm}$. Upon addition of $\mathrm{NaPF}_{6}$, a new peak appeared as a broad feature between 7.9 and 7.5 ppm (Fig. S10 in the Supporting Information). It is probable that this was from trace water present in the $\mathrm{Na}^{+}$salt. The peak became progressively deshielded until, after $18 \mathrm{~h}$, it had sharpened and was centred at 10.5 ppm. Integration indicated that it corresponded to four protons for each calixarene, consistent with two water molecules to every $\mathrm{Na}^{+} \cdot 1,3$-alt $\mathbf{4}$ complex. Taken together these changes suggested that the cation was not associated with the polyether region of the molecule but resided inside the annulus of the calixarene initially interacting most strongly with the aryl carbons and protons on the methylene bridge. Over time two water molecules coordinate to the bound cation down the axis of the calixarene. Hydration was evident within two minutes of the salt being added but took almost 20 $\mathrm{h}$ to reach completion. As a control, the experiment was repeated using $\mathrm{NH}_{4} \mathrm{PF}_{6}$ over a $96 \mathrm{~h}$ period. Protons on the methylene bridge and, crucially, all those associated with the polyether region of the molecule were deshielded by 0.05 to $0.07 \mathrm{ppm}$ as would be expected if the cation was interacting with the polyether substituents. No evidence of bound water was observed.

In the absence of crystallographic evidence a computer simulation was used to gain some insight into the probable position of a $\mathrm{Na}^{+}$guest within the calixarene host. We 
have previously shown that even simple molecular mechanics geometry optimizations can give models of host-guest complexes that compare favourably with information drawn from NMR binding studies [36] and that gas phase PM3 calculations can provide good models for inclusion phenomena in solution [37].

Computer models of 1,3-alt $\mathbf{4}$ and cone 4, generated as described in the Experimental section, suggested stable extended structures in both cases with cone $\mathbf{4}$ in the 'flattened cone' conformation having $C_{2 v}$ symmetry and 1,3-alt $\mathbf{4}$ in the expected 1,3alternate $S_{4}$ conformation as shown in Fig. 2. Molecular modelling of the $\mathrm{Na}^{+}$ complex was undertaken using semiempirical methods (restricted HF/PM3) where two starting positions were considered for $\mathrm{Na}^{+}$. In these the cation was either placed close to the macrocyclic annulus or near the ends of two polyether substituents. In the former case (structure I) the cation was drawn into the macrocyclic annulus with no polyether-cation interactions. In the latter case (structure II) the cation bound by the macrocycle was also enfolded by one polyether substituent to give a coordination environment reminiscent of a cation-calixcrown complex. The heats of formation for the two structures $\left(-2120 \mathrm{~kJ} \mathrm{~mol}^{-1}\right.$ for I vs. $-2169 \mathrm{~kJ} \mathrm{~mol}^{-1}$ for II), illustrated in Fig. 3, were within $2.5 \%$. Structure I had closest contacts between $\mathrm{Na}^{+}$and four coplanar carbon atoms at the lower rim in good agreement with density functional calculations for the $\mathrm{Na}^{+} \cdot 1,3$-alt calix[4]arene complex [38]. More importantly it was consistent with the NMR shifts in the bridging methylene and aromatic protons following the addition of $\mathrm{Na}^{+}$. Geometry optimized dihydrate structures were generated from structures I and II of the $\mathrm{Na}^{+} \cdot 1,3$-alt $\mathbf{4 b}$ complex as shown in Fig. 3. Structure I optimized with water molecules along the axis of the calixarene at distances of 2.7 to $2.8 \AA$ from the cation. $\mathrm{Na}^{+}$had other close contacts from phenolic ether oxygen atoms 
at $2.6 \AA$ and two aromatic centroids at $2.7 \AA$. In structure II one water molecule adopted an axial position $2.8 \AA$ from the cation while the other displaced the polyether and bridged between the ether oxygen atoms and the cation. The heats of formation were within $2 \%$ of each other $\left(-2625 \mathrm{~kJ} \mathrm{~mol}^{-1}\right.$ for structure I vs. $-2678 \mathrm{~kJ}$ $\mathrm{mol}^{-1}$ for structure II). Perhaps surprisingly, these calculations indicated that even if polyether interactions were important in the formation of $\mathrm{Na}^{+} \cdot 1,3$-alt $\mathbf{4 b}$ complexes, water molecules could displace the more weakly bound ethers in the cation's primary coordination sphere.

Given that 1,3-alt $\mathbf{4}$ approaches $3 \mathrm{~nm}$ in length when fully extended its potential to act as an artificial transmembrane ion channel was investigated using a planar lipid bilayer method. Solutions of 1,3-alt $\mathbf{4}$ were added to a planar lipid bilayer bathed in biomimetic Ringer's solution containing either $\mathrm{K}^{+}$or $\mathrm{Na}^{+}$at a concentration of 150 $\mathrm{mM}$ [39]. In total five recordings were made with $\mathrm{K}^{+}$and three with $\mathrm{Na}^{+}$using a new bilayer in each case. Insertion of 1,3-alt $\mathbf{4}$ was indicated by a perturbation of the membrane shortly after the compound was introduced though no occurrences of the membrane busting were observed as a result. Fig. 4 shows a typical example of bilayer activity following insertion of 1,3-alt 4. All recordings of experiments involving $\mathrm{K}^{+}$showed the level of membrane activity increasing with time as in the upper trace of Fig. 4 though no features corresponding to channels were observed. In two of the experiments where $\mathrm{Na}^{+}$was present channel-like features were recorded: in a third an increasing current exhibiting some stepped features was observed but the bilayer burst without giving a long lasting channel-like response. Where channel formation was observed it usually appeared 10 seconds after the addition of 1,3-alt 4 and lasted for up to $60 \mathrm{~s}$. Several examples of these stepped features were detected 
during the course of both successful experiments. The lower trace in Fig. 4 shows a section from a typical experiment involving $\mathrm{Na}^{+}$. The steps were on the scale of 100 $\mathrm{pS}$ implying insertion of several calixarenes in a manner that we have described with regard to a calix[6]arene derivative [33]. The integrity of the bilayer held throughout the experiments.

\section{CONCLUSIONS}

The synthesis of 1,3-alt $\mathbf{4}$ has been described and the compound shown by NMR to bind $\mathrm{Na}^{+}$. Over time the cation also attracted water, present in trace amounts in the $\mathrm{Na}^{+}$salt, to form a dihydrate. Computational simulations agree with the NMR data in predicting $\mathrm{Na}^{+}$binding within the annulus of the calixarene. The models indicate that this may be facilitated by interactions with oxygen atoms in a polyether substituent. Simulation of a hydrated complex mirrored the observation that two water molecules were incorporated in the complex during the NMR experiment performed in $\mathrm{CDCl}_{3}$. The process of metal binding and hydration would be expected to be significantly faster when 1,3-alt $\mathbf{4}$ was inserted in a bilayer bathed by water on both sides.

Lipid bilayer experiments confirmed that 1,3-alt 4 functions as an artificial transmembrane ion channel in the presence of $\mathrm{Na}^{+}$but not $\mathrm{K}^{+}$. Why does this calixarene act as a $\mathrm{Na}^{+}$channel when other compounds related to calix[4]arenes are $\mathrm{K}^{+}$selective? The answer lies in its conformation. Shinkai has proposed that the 1,3alternate conformer of calix[4]arene provides an extended electron rich environment that is attractive to monovalent cations [40]. Evidence from NMR experiments and molecular simulations suggests that $\mathrm{Na}^{+}$is in its preferred six-coordinate environment 
in 1,3-alt 4 interacting with two water molecules, two phenolic oxygens and two aromatic rings. This is consistent with current thinking on cation channel mechanisms which indicate that conductance occurs as water-linked chains of partially dehydrated cations pass through channel selectivity filters [8,15]. Calix[4]arene 1,3-alt $\mathbf{4}$ is therefore ideally suited as a synthetic ion channel for $\mathrm{Na}^{+}$.

\section{Supporting Information}

NMR spectra for compounds $\mathbf{2}, \mathbf{3}, 1,3$-alt $\mathbf{4}$ and cone $\mathbf{4}, 1,3$-alt $\mathbf{4} \cdot \mathrm{Na}^{+} \cdot 2 \mathrm{H}_{2} \mathrm{O}$ together with HRMS spectra for 1,3-alt $\mathbf{4}$ and cone $\mathbf{4}$ are available as supplementary information.

\section{Acknowledgements}

We thank the University of Brighton for financial support (for K. S. J. I. and F. F.)

\section{References}

[1] Takaki, U.; Hogen Esch, T. E.; Smid, J. J. Am. Chem. Soc., 1971, 93, 6760;

McLaughlin, S. G. A.; Szabo, G.; Ciani, S.; Eisenman, G. J. Membrane Biol., 1972, 9 , 3.

[2] Raymond, K. N.; Isied, S. S.; Brown, L. D.; Fronczek, F. R.; Nibert, J. H. J. Am. Chem. Soc., 1976, 98, 1767.

[3] Kirby, A. Angew. Chem. Int. Ed. Engl., 1996, 35, 707.

[4] Cragg, P. J. Science Progress, 2002, 85, 219.

[5] Liang, X.; Campopiano, D, J.; Sadler, P. J. Chem. Soc. Rev., 2007, 36, 968.

[6] Insight: ion channels, in Nature, 2006, 440, pp. 439-489.

[7] Zhorov, B. S.; Tikhonov, D. B. J. Neurochem., 2004, 88, 782. 
[8] Doyle, D.; Morais Cabral, J.; Pfuetzner, R. A.; Kuo, A.; Gulbis, J. M.; Cohen, S. L.; Chait, B. T.; MacKinnon, R. Science, 1998, 280, 69.

[9] Jiang, Y.; Lee, A.; Chen, J.; Cadene, M.; Chait, B. T.; MacKinnon, R. Nature, 2002, 417, 515 .

[10] Hattori, M.; Tanaka, Y.; Fukai, S.; Ishitani, R.; Nureki, O. Nature, 2007, 448, 1072.

[11] Shi, N.; Ye, S.; Alam, A.; Chen, L.; Jiang, Y. Nature, 2006, 440, 570.

[12] Morth, J. P.; Pedersen, B. P.; Toustrup-Jensen, M. S.; Sørensen, T. L.-M.; Petersen, J.; Andersen, J. P.; Vilsen, B.; Nissen, P. Nature, 2007, 450, 1043.

[13] Jasti, J.; Furukawa, H.; Gonzales, E. B.; Gouaux, E. Nature, 2007, 449, 316.

[14] Farid, R.; Day, T.; Friesner, R. A.; Pearlstein, R. A. Bioorg. Med. Chem., 2006, $14,3160$.

[15] Noskov, S. Y.; Bernèche, S.; Roux, B. Nature, 2004, 431, 830.

[16] Dock, A. C.; Moras, D.; Behr, J. P.; Lehn, J.-M. Acta Cryst. C, 1983, 39, 1001.

[17] Fyles, T. M.; James, T. D.; Kaye, K. C. J. Am. Chem. Soc., 1993, 115, 12315.

[18] Gokel, G. W. Chem. Commun., 2000, 1.

[19] Hall, C. D.; Kirkovits, G.J.; Hall, A.C. Chem. Commun., 1999, 1897

[20] Tanaka, Y.; Kobuke, Y.; Sokabe, M. Angew. Chem. Int. Ed. Engl., 1995, 34, 693

[21] Wright, A. J.; Matthews, S. E.; Fischer, W. B.; Beer, P. D. Chem. Eur. J., 2001, 7,3474 .

[22] Iqbal, K. S. J; Cragg, P. J. Dalton Trans., 2007, 26.

[23] de Mendoza, J.; Cuevas, F.; Prados, P.; Meadows, E. S.; Gokel, G. W. Angew. Chem. Int. Ed. Engl., 1998, 37, 1534.

[24] Kobuke, Y.; Nagatani, T. J. Org. Chem., 2001, 66, 5094. 
[25] Baklouti, L.; Harrowfield, J.; Pulpoka, B.; Vicens, J. Mini Rev. Org. Chem., 2006, 3, 355 .

[26] Schalley, C. A. Mass Spectrom. Rev., 2001, 20, 253.

[27] Gutsche, C. D.; Levine, J. A.; Sujeeth, P. K. J. Org. Chem., 1985, 50, 5802.

[28] General method from Loiseau, F. A.; Hill, A. M.; Hii, K. K. Tetrahedron, 2007, $63,9947$.

[29] Verboom, W.; Datta, S.; Asfari, Z.; Harkema, S.; Reinhoudt, D. N. J. Org. Chem., 1992, 57, 5394.

[30] Wavefunction, Inc., Irvine, CA, USA.

[31] Hardy, S. P.; Richie, C.; Allen, M. C.; Ashley, R. H.; Granum, P. E. BBA Biomembranes, 2001, 1515, 38.

[32] Cragg, P. J.; Allen, M. C.; Steed, J. W. Chem. Commun., 1999, 553.

[33] Iqbal, K. S. J.; Allen, M. C.; Fucassi, F.; Cragg, P. J. Chem. Commun., 2007, 3951.

[34] Matthews, S. E.; Schmitt, P.; Felix, V.; Drew, M. G. B.; Beer, P. D. J. Am. Chem. Soc., 2002, 124, 1341.

[35] Jaime, C.; de Mendoza, J.; Prados, P.; Nieto, P. D.; Sánchez, C. J. Org. Chem., 1991, 56, 3372 .

[36] Marcos, P. M.; Ascenso, J. R.; Cragg, P. J. Supramol. Chem., 2007, 19, 199.

[37] Sheehan, R.; Cragg.; P. J. Supramol. Chem., 2007, 20, 437.

[38] Macias, A.; Norton, J. E.; Evanseck, J. D. J. Am. Chem. Soc., 2003, 125, 2351.

[39] A similar bilayer experiment in $\mathrm{Na}^{+}$rich media carried out using the crude mixture of cone compounds, including cone 4, also demonstrated insertion into the lipid membrane but no transmembrane ion current was observed [data not shown]. As 
1

2

3

4

5

6

7

8

9

10

11

12

13

14

15

16

17

18

19

20

21

22

23

24

25

26

27

28

29

30

31

32

33

34

35

36

37

38

39

40

41

42

43

44

45

46

47

48

49

50

51

52

53

54

55

56

57

58

59

60

the cone compounds are $c a .1 .7 \mathrm{~nm}$ when fully extended it is probable that they are unable to span the bilayer and therefore cannot form conducting channels.

[40] Ikeda, A.; Shinkai, S. J. Am. Chem. Soc., 1994, 116, 3102. 


\section{List of figures}

SCHEME 1. Synthesis of calixarenes: i) $\mathrm{TsCl}, \mathrm{NaOH}_{(\mathrm{aq})}, 1,4$-dioxane, $0^{\circ} \mathrm{C}$; ii) $\mathrm{KI}$, acetone, reflux; iii) calix[4]arene, $\mathrm{K}_{2} \mathrm{CO}_{3}$ or $\mathrm{Cs}_{2} \mathrm{CO}_{3}, \mathrm{CH}_{3} \mathrm{CN}$, reflux.

FIGURE 1. Time dependent changes in the ${ }^{1} \mathrm{H}$ spectrum of 1,3-alt 4 following addition of $\mathrm{NaPF}_{6}(\boldsymbol{\Delta}=$ aromatic protons in the 3 and 5 positions; $\mathbf{a}=$ aromatic protons in the 4 position; $\bullet=$ methylene bridge protons; $\mathrm{x}=$ chloroform).

FIGURE 2. Simulated ligand structures: a) 1,3-alt $\mathbf{4}$ (side and top); b) cone $\mathbf{4}$ (side and top).

FIGURE 3. Simulated complex structures: a) 1,3 -alt $\mathbf{4} \cdot \mathrm{Na}^{+}$, structure I; b) 1,3-alt 4. $\mathrm{Na}^{+} \cdot 2 \mathrm{H}_{2} \mathrm{O}$, structure I; c) 1,3 -alt $4 \cdot \mathrm{Na}^{+}$, structure II; d) 1,3-alt $\mathbf{4} \cdot \mathrm{Na}^{+} \cdot 2 \mathrm{H}_{2} \mathrm{O}$, structure II.

FIGURE 4. Transmembrane activity of 1,3-alt 4: with $\mathrm{K}^{+}$(upper trace) and $\mathrm{Na}^{+}$ (lower trace, with minor signal dropout). 
1

2

3

4

5

6

7

8

9

10

11

12

13

14

15

16

17

18

19

20

21

22

23

24

25

26

27

28

29

30

31

32

33

34

35

36

37

38

39

40

41

42

43

44

45

46

47

48

49

50

51

52

53

54

55

56

57

58

59

60

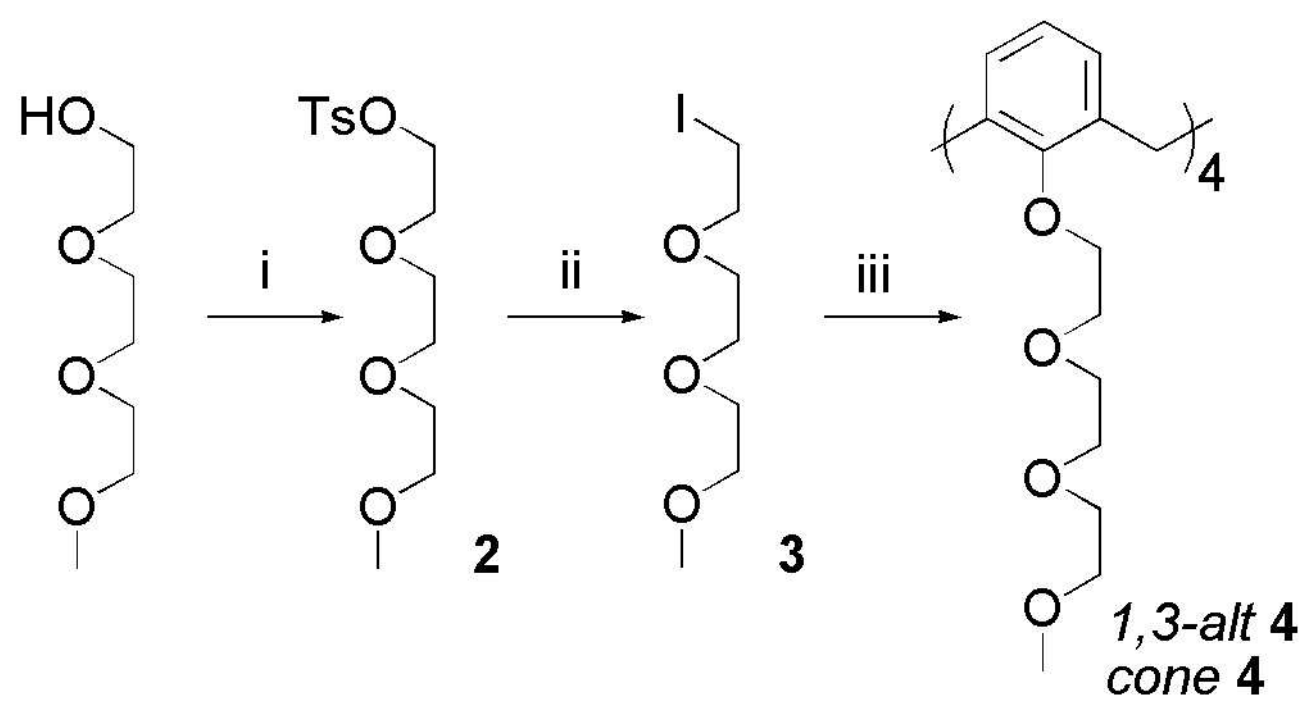

SCHEME 1. Synthesis of calixarenes: i) $\mathrm{TsCl}, \mathrm{NaOH}(\mathrm{aq}), 1$,4-dioxane, $0^{\circ} \mathrm{C}$; ii) $\mathrm{KI}$, acetone, reflux; iii) calix[4]arene, $\mathrm{K} 2 \mathrm{CO} 3$ or $\mathrm{Cs} 2 \mathrm{CO} 3, \mathrm{CH} 3 \mathrm{CN}$, reflux. $86 \times 46 \mathrm{~mm}(300 \times 300 \mathrm{DPI})$

URL: http:/mc.manuscriptcentral.com/tandf/gsch Email: suprachem@mail.cm.utexas.edu 
FIGURE 1. Time dependent changes in the $1 \mathrm{H}$ spectrum of 1,3 -alt 4 following addition of NaPF6 ( $\Delta$ $=$ aromatic protons in the 3 and 5 positions; $\mathbf{.}=$ aromatic protons in the 4 position; $\bullet=$ methylene bridge protons; $x=$ chloroform). $597 \times 345 \mathrm{~mm}(96 \times 96 \mathrm{DPI})$ 
1

2

3

4

5

6

7

8

9

10

11

12

13

14

15

16

17

18

19

20

21

22

23

24

25

26

27

28

29

30

31

32

33

34

35

36

37

38

39

40

41

42

43

44

45

46

47

48

49

50

51

52

53

54

55

56

57

58

59

60

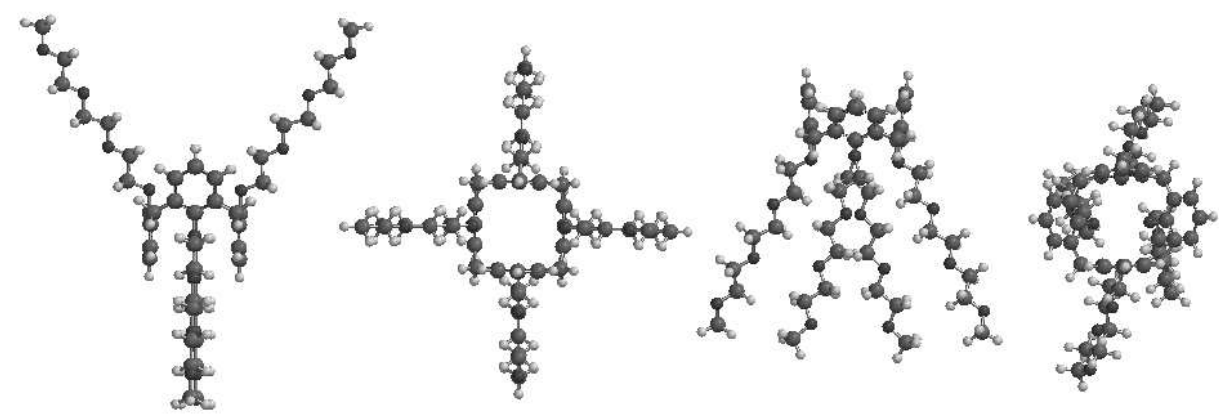

b

FIGURE 2. Simulated ligand structures: a) 1,3-alt 4 (side and top); b) cone 4 (side and top). $268 \times 123 \mathrm{~mm}(96 \times 96 \mathrm{DPI})$ 


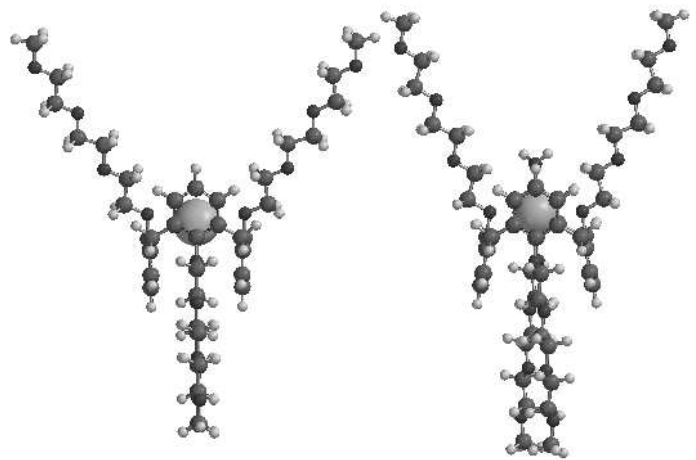

a

b

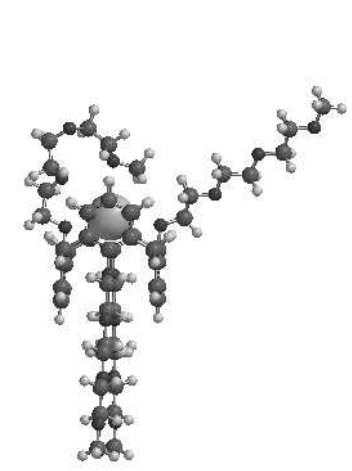

c

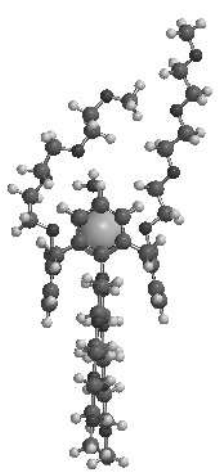

d

\section{FIGURE 3. Simulated complex structures: a) 1,3-alt 4Â $\square \mathrm{Na}+$, structure I; b) 1,3-alt 4ÂaNa+Â $\square 2$ $\mathrm{H} 2 \mathrm{O}$, structure I; c) 1,3-alt 4ÂA $\square \mathrm{Na}$, structure II; d) 1,3-alt 4Â $\square \mathrm{Na}+\hat{\mathrm{A}} \square 2 \mathrm{H} 2 \mathrm{O}$, structure II. $343 \times 215 \mathrm{~mm}(75 \times 75$ DPI $)$}


FIGURE 4. Transmembrane activity of 1,3-alt 4: with $\mathrm{K}+$ (upper trace) and $\mathrm{Na}+$ (lower trace, with minor signal dropout). $189 \times 103 \mathrm{~mm}$ (96 x 96 DPI)

URL: http:/mc.manuscriptcentral.com/tandf/gsch Email: suprachem@mail.cm.utexas.edu 
An artificial sodium ion channel from calix[4]arene in the 1,3-alternate conformation

O. Lawal, K. S. J. Iqbal, A. Mohamadi, P. Razavi, H. T. Dodd, M. C. Allen, S. Siddiqui, F. Fucassi and P. J. Cragg

Supporting Information

Figure S1. ${ }^{1} \mathrm{H}$ NMR for 2.

Figure S2. ${ }^{13} \mathrm{C}$ NMR for 2.

Figure S3. ${ }^{1} \mathrm{H}$ NMR for 3 .

Figure S4. ${ }^{13} \mathrm{C}$ NMR for 3 .

Figure S5. ${ }^{1} \mathrm{H}$ NMR for 1,3 -alt 4.

Figure S6. ${ }^{13} \mathrm{C}$ NMR for 1,3-alt 4 .

Figure S7. ${ }^{1} \mathrm{H}$ NMR for crude cone 4.

Figure S8. ${ }^{13} \mathrm{C}$ NMR for crude cone 4 .

Figure S9. Mass spectra for 1,3-alt $\mathbf{4}$ and crude cone $\mathbf{4}$.

Figure S10. ${ }^{1} \mathrm{H}$ NMR for 1,3 -alt $4 \cdot \mathrm{Na}^{+} \cdot 2 \mathrm{H}_{2} \mathrm{O}\left(18.5 \mathrm{~h}\right.$ after addition of $\left.\mathrm{NaPF}_{6}\right)$.

Table S1. Time dependent shifts (ppm) for selected nuclei after addition of $\mathrm{NaPF}_{6}$. 


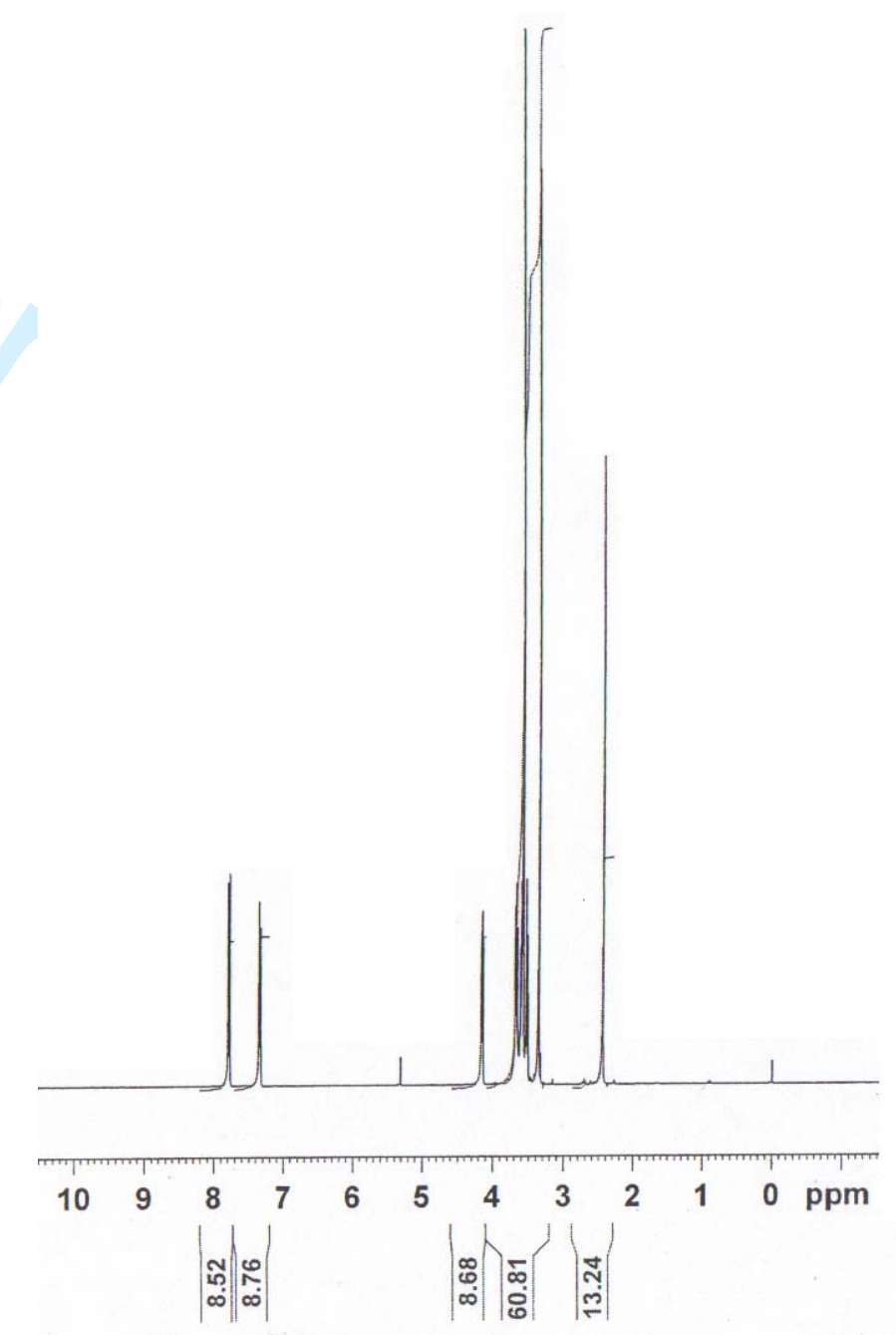

Figure S1. ${ }^{1} \mathrm{H}$ NMR for 2 .

URL: http:/mc.manuscriptcentral.com/tandf/gsch Email: suprachem@mail.cm.utexas.edu 


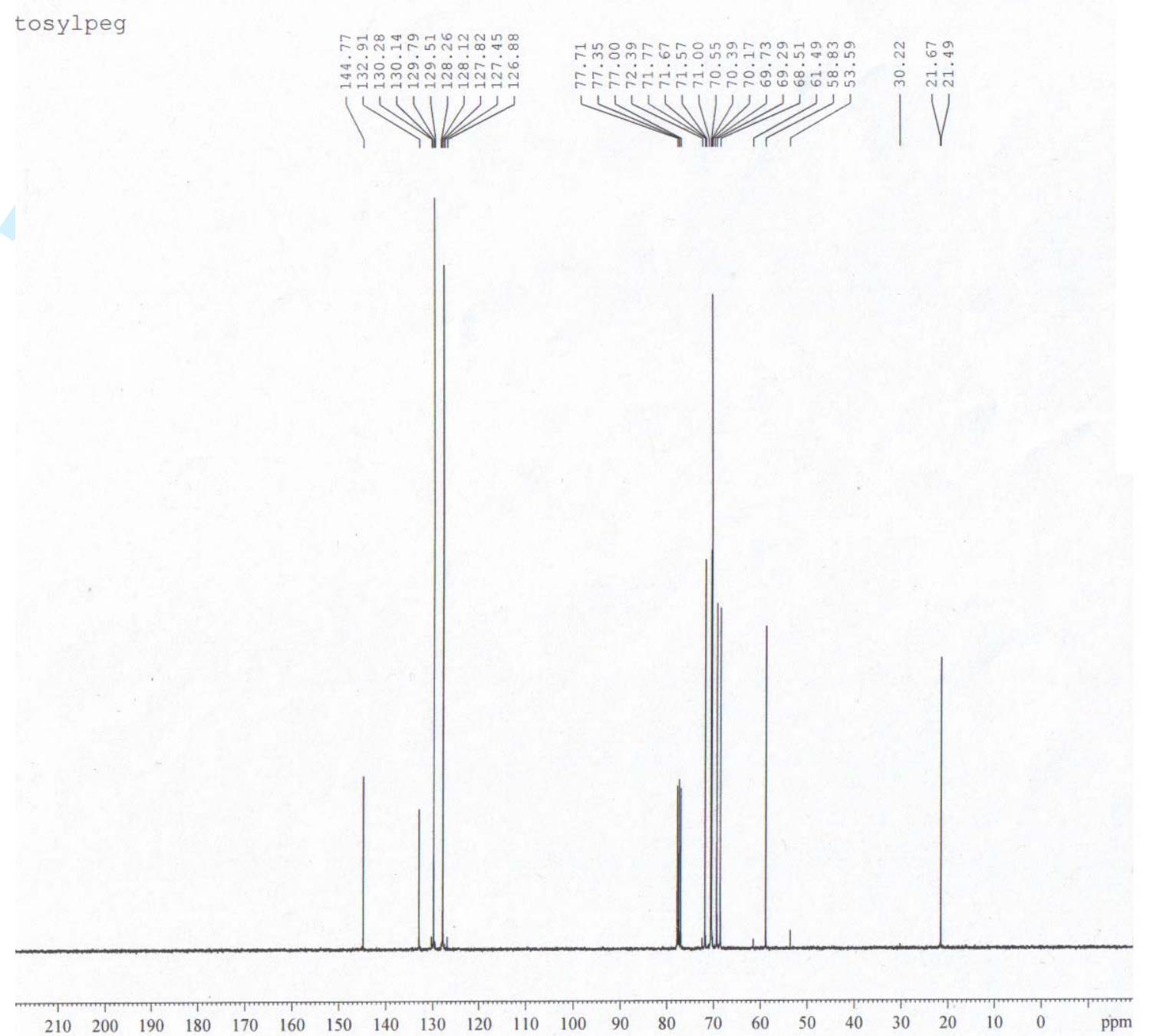

Figure S2. ${ }^{13} \mathrm{C}$ NMR for 2. 


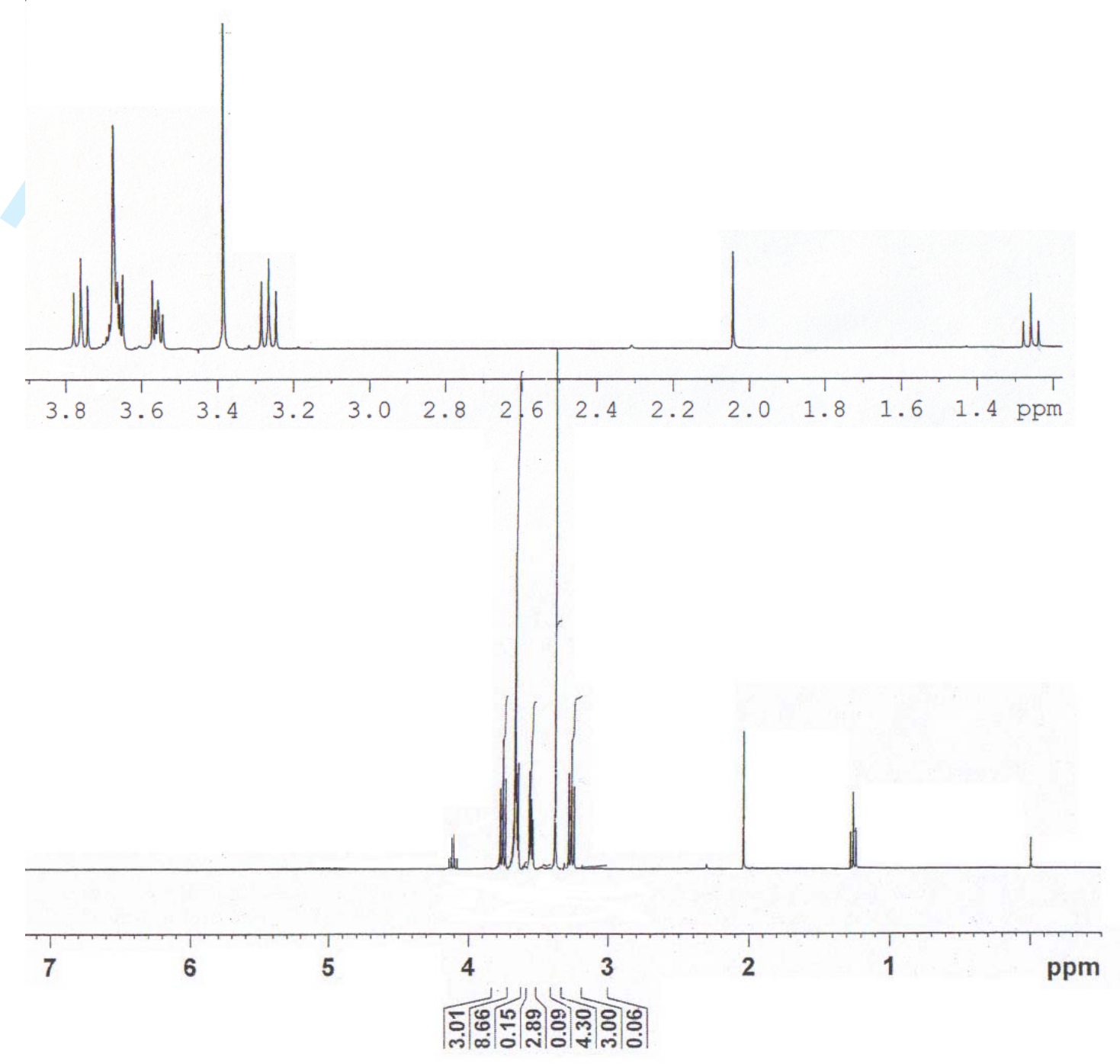

Figure S3. ${ }^{1} \mathrm{H}$ NMR for 3 (trace of ethyl acetate present).

URL: http:/mc.manuscriptcentral.com/tandf/gsch Email: suprachem@mail.cm.utexas.edu 


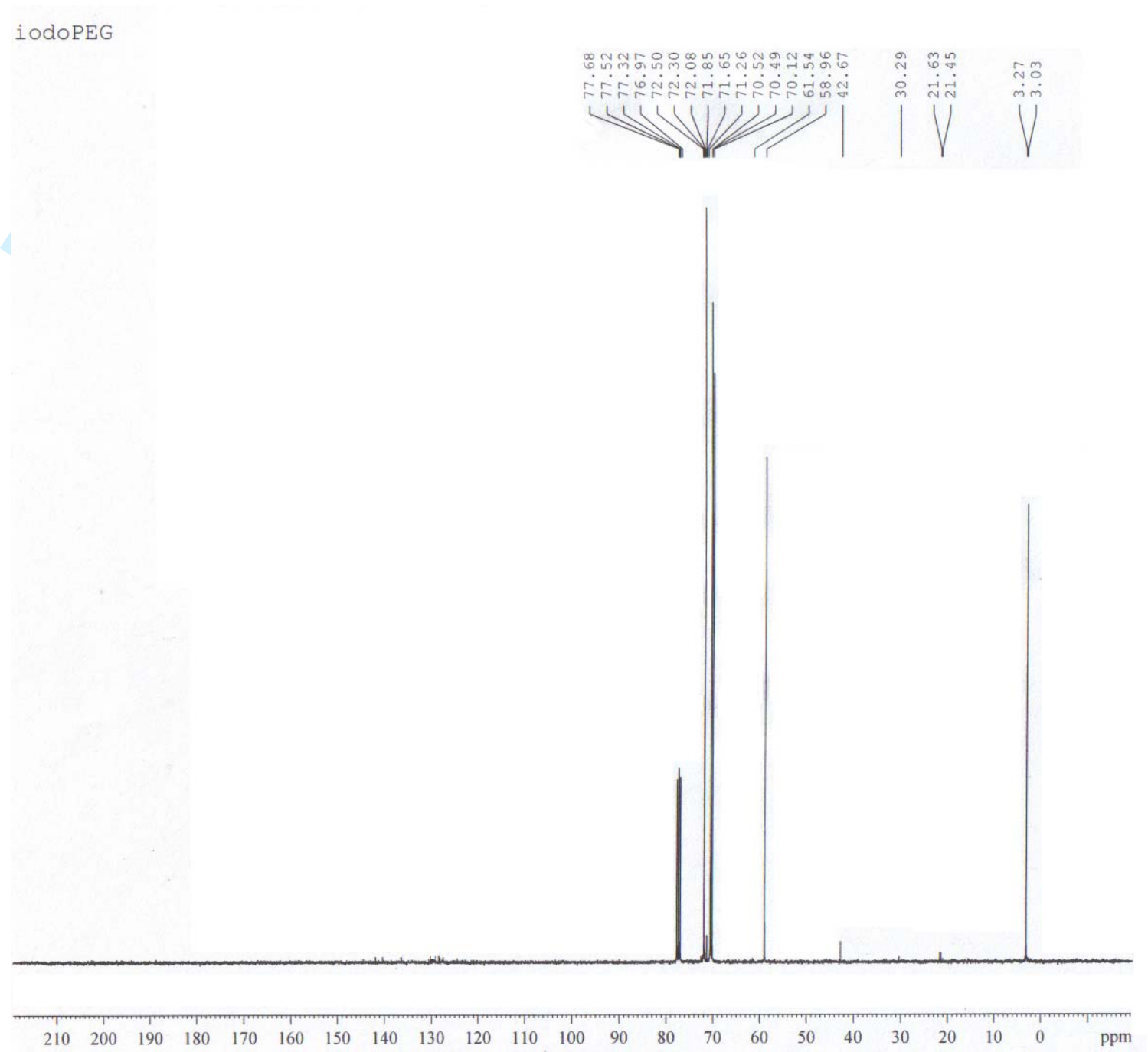

Figure S4. ${ }^{13} \mathrm{C}$ NMR for 3 (trace of ethyl acetate present).

URL: http:/mc.manuscriptcentral.com/tandf/gsch Email: suprachem@mail.cm.utexas.edu 

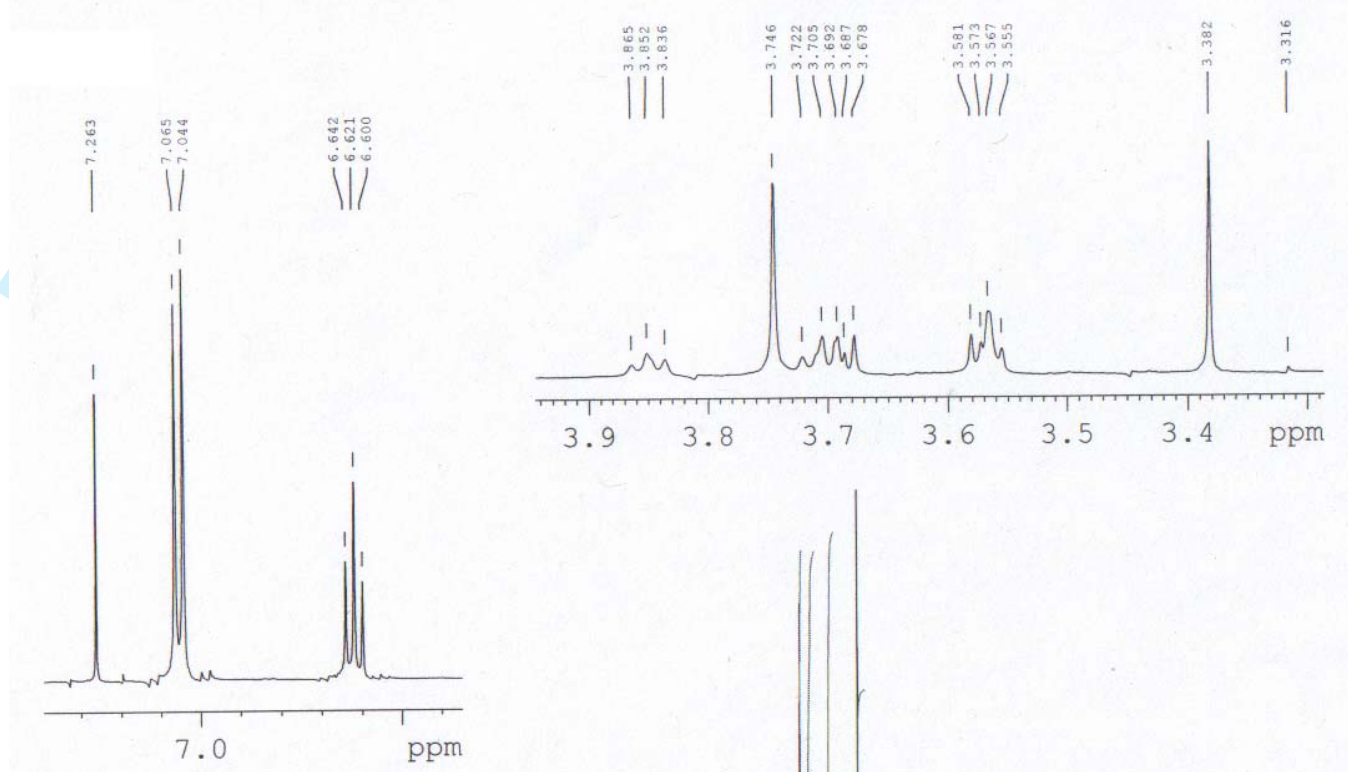

Figure S5. ${ }^{1} \mathrm{H}$ NMR for 1,3 -alt 4. 


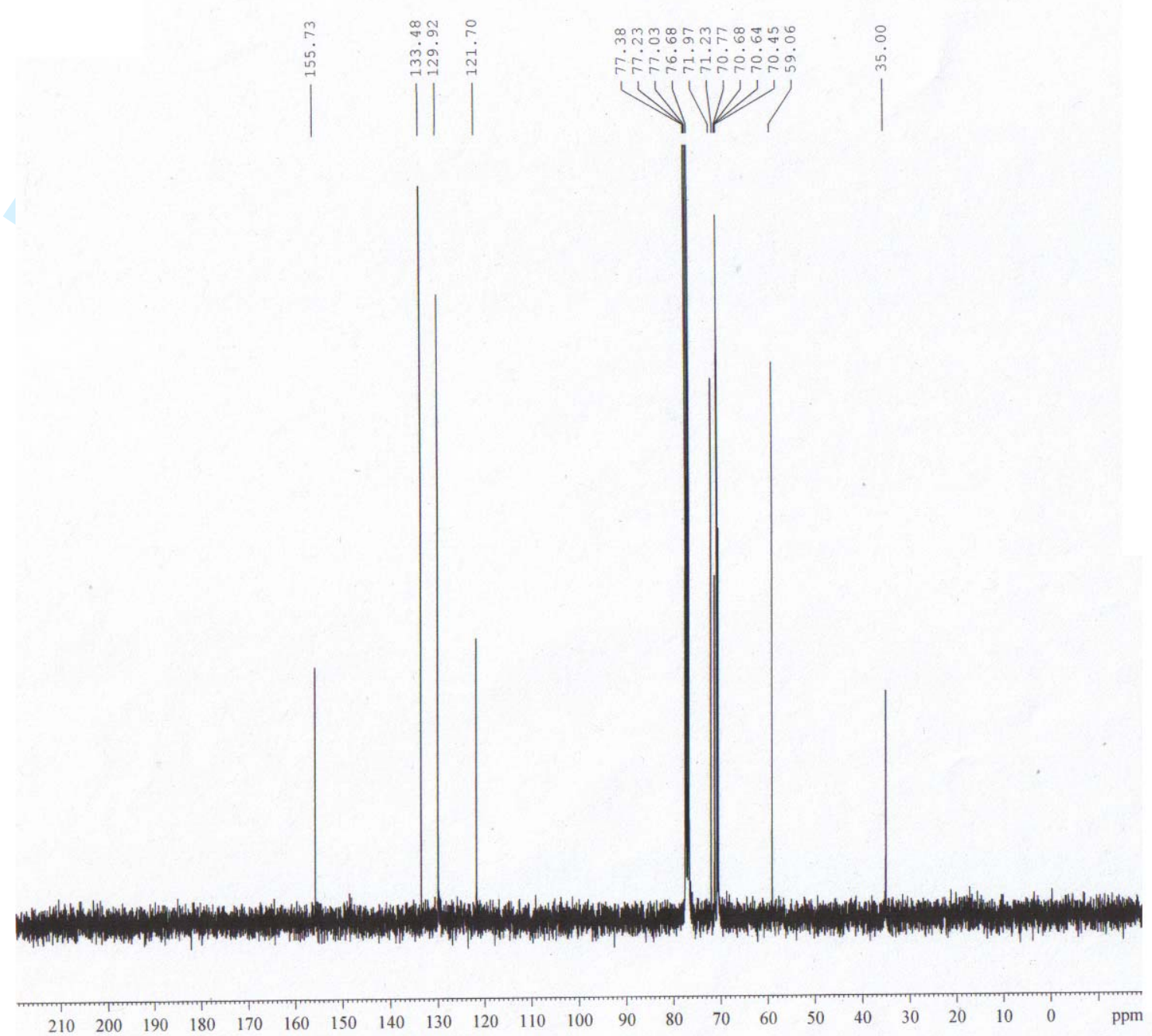

Figure S6. ${ }^{13} \mathrm{C}$ NMR for 1,3-alt 4.

URL: http:/mc.manuscriptcentral.com/tandf/gsch Email: suprachem@mail.cm.utexas.edu 


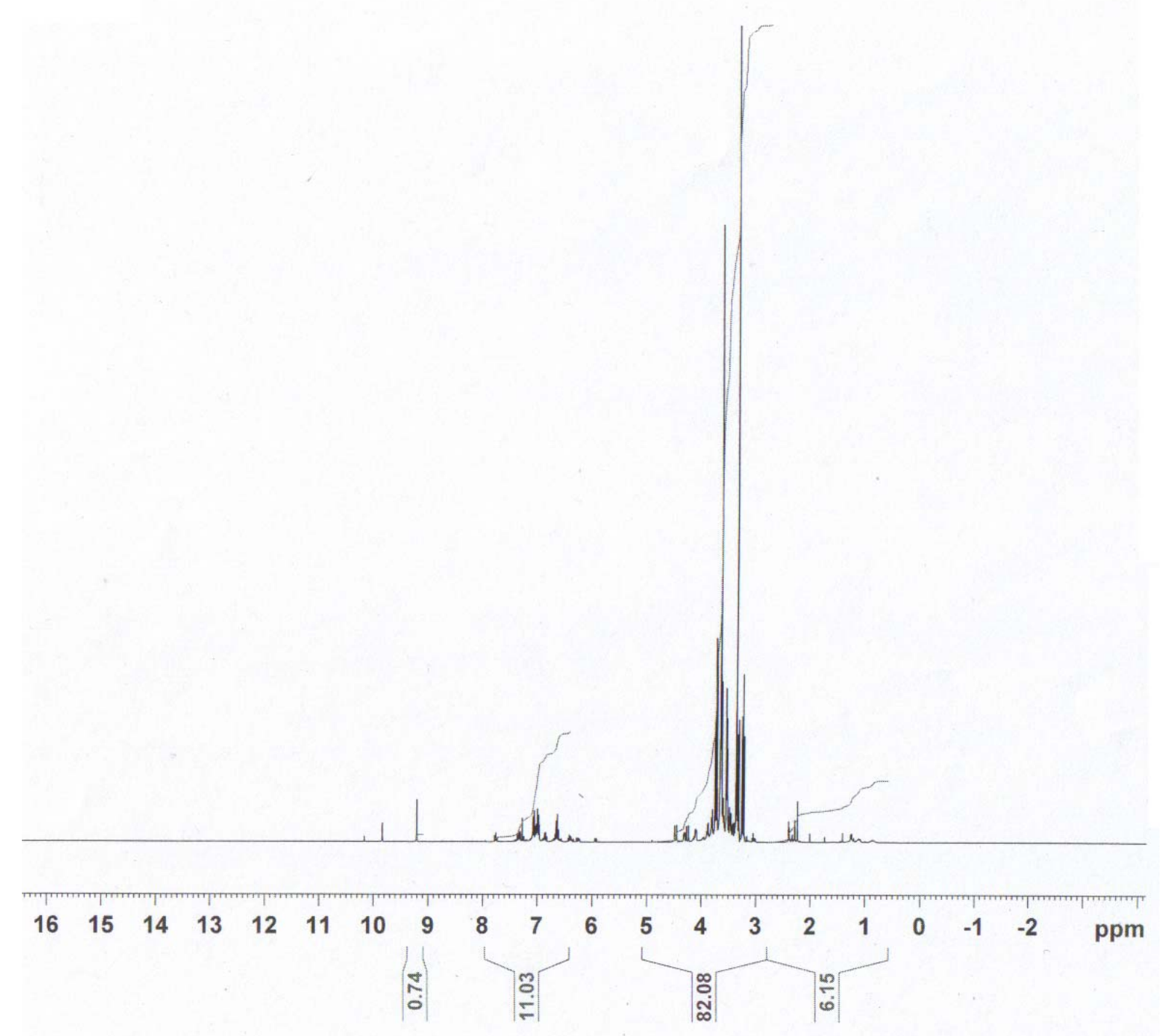

Figure S7. ${ }^{1} \mathrm{H}$ NMR for crude cone 4.

URL: http:/mc.manuscriptcentral.com/tandf/gsch Email: suprachem@mail.cm.utexas.edu 


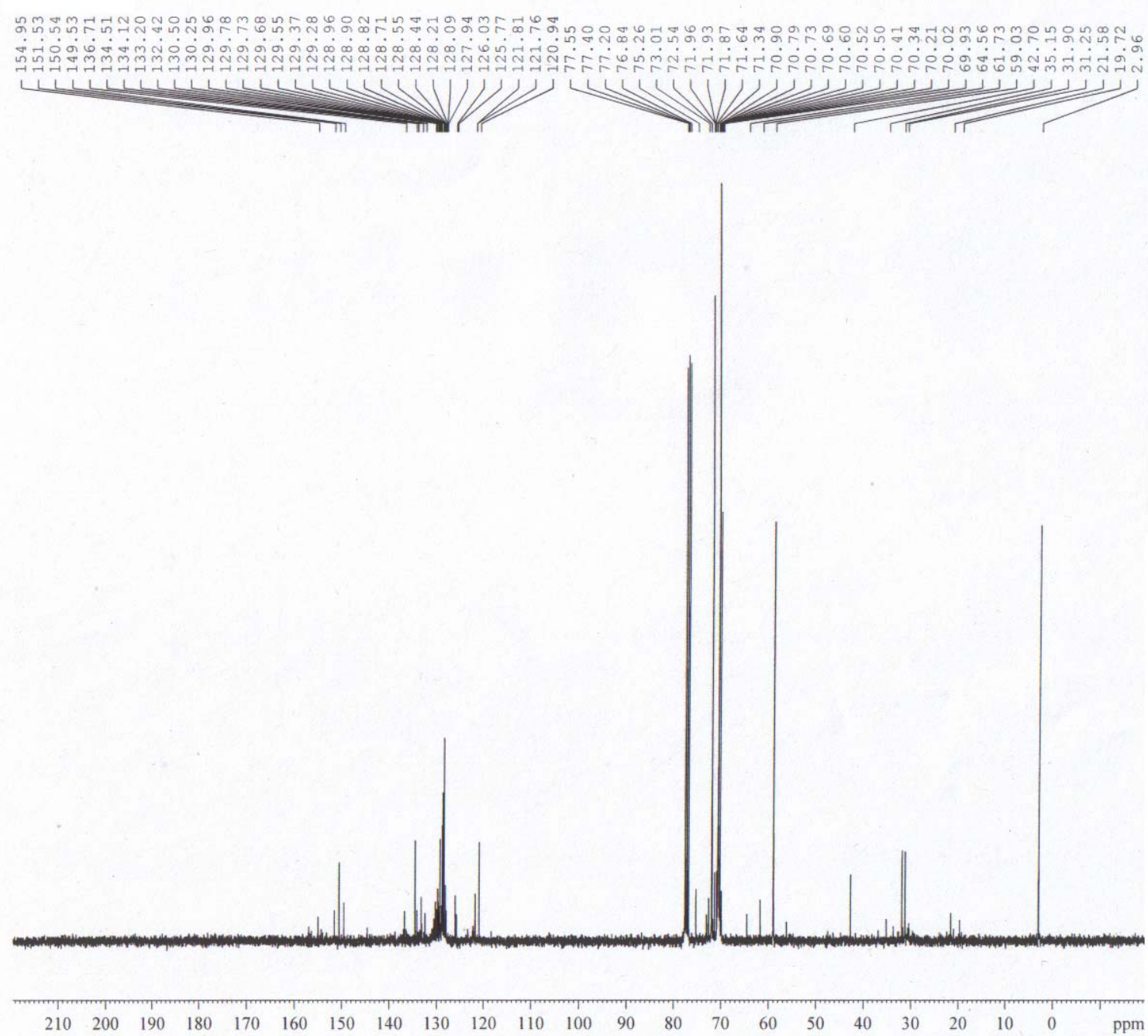

Figure S8. ${ }^{13} \mathrm{C}$ NMR for crude cone 4 .

URL: http:/mc.manuscriptcentral.com/tandf/gsch Email: suprachem@mail.cm.utexas.edu 


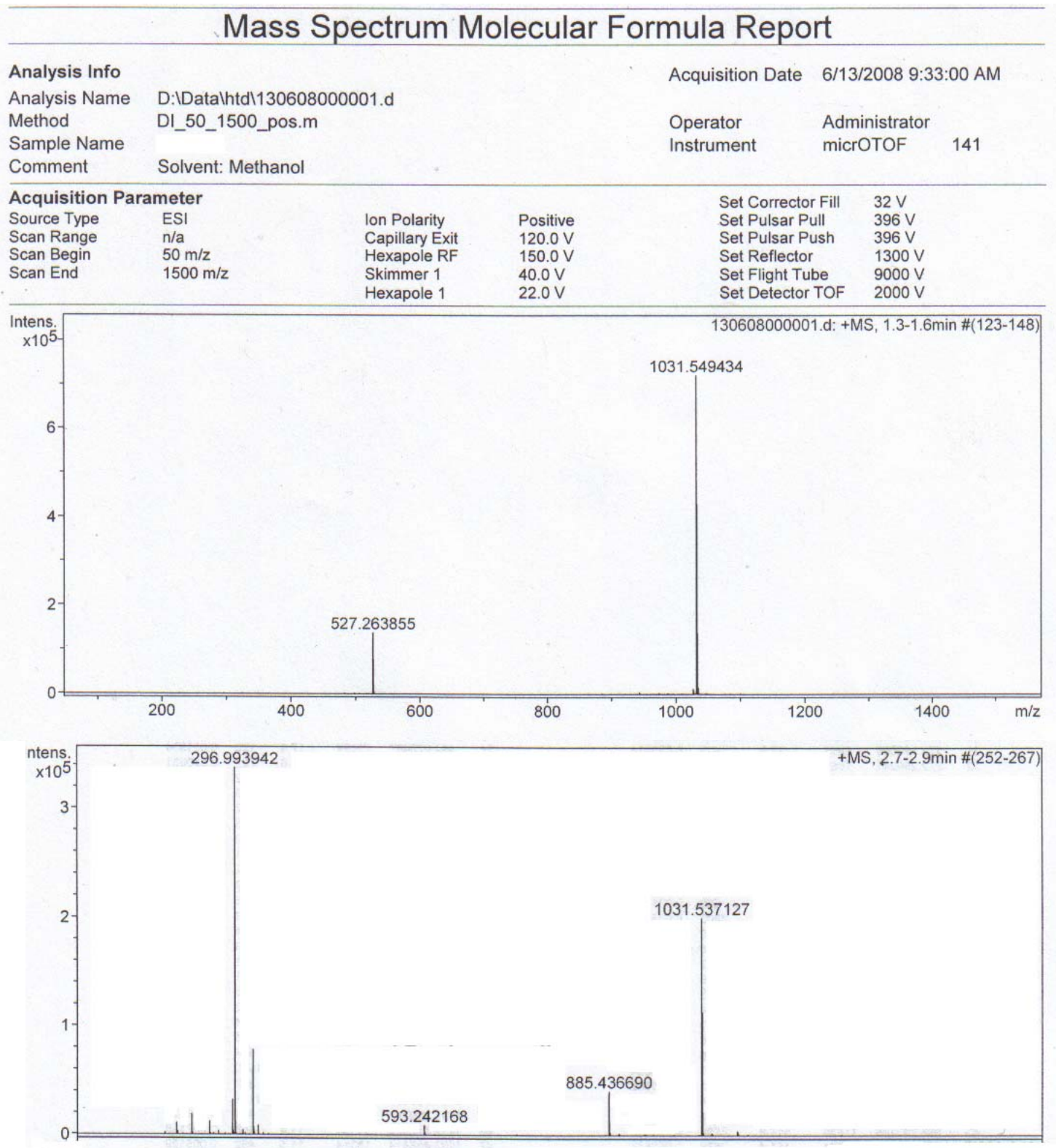

Figure S9. Mass spectra for 1,3-alt 4 (upper scan) and crude cone 4 (lower scan) 


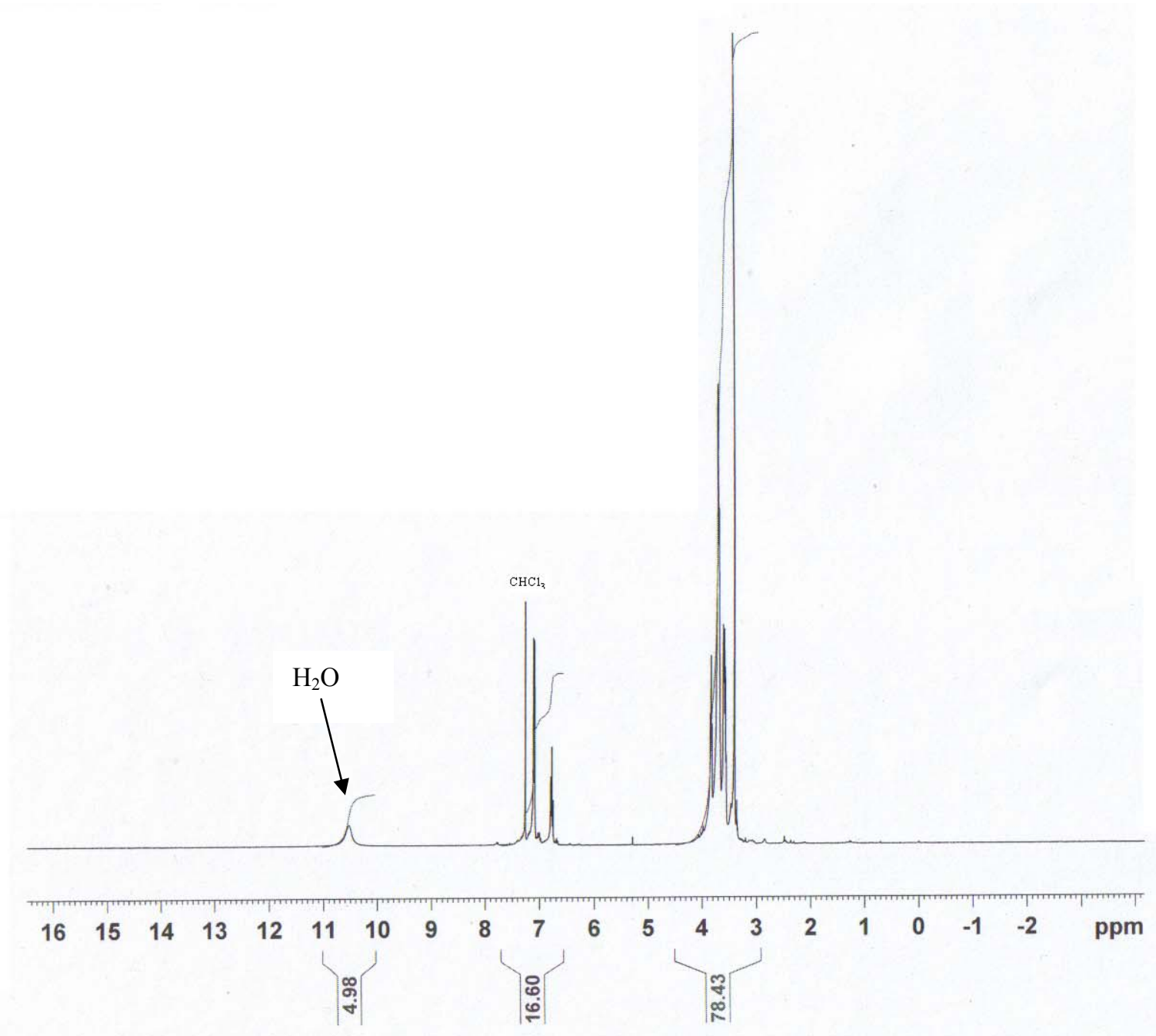

Figure S10. ${ }^{1} \mathrm{H}$ NMR for 1,3 -alt $\mathbf{4} \cdot \mathrm{Na}^{+} \cdot 2 \mathrm{H}_{2} \mathrm{O}\left(18.5 \mathrm{~h}\right.$ after addition of $\left.\mathrm{NaPF}_{6}\right)$.

URL: http:/mc.manuscriptcentral.com/tandf/gsch Email: suprachem@mail.cm.utexas.edu 
<smiles>CCc1cccc(C)c1OCCOCCOCCOC</smiles>

\begin{tabular}{|l|l|l|}
\hline $\mathbf{C}$ & $\begin{array}{l}0 \\
\min \end{array}$ & $\begin{array}{l}18.5 \\
\mathrm{~h}\end{array}$ \\
\hline $\mathbf{1}$ & 121.7 & 122.9 \\
\hline $\mathbf{2}$ & 133.5 & 133.8 \\
\hline $\mathbf{3}$ & 129.9 & 130.2 \\
\hline $\mathbf{4}$ & 155.7 & 155.4 \\
\hline $\mathbf{5}$ & 35.0 & 36.2 \\
\hline
\end{tabular}

\begin{tabular}{|l|l|l|l|l|l|}
\hline $\mathbf{H}$ & $\begin{array}{l}0 \\
\min \end{array}$ & $\begin{array}{l}2 \\
\min \end{array}$ & $\begin{array}{l}27 \\
\min \end{array}$ & $\begin{array}{l}84 \\
\min \end{array}$ & $\begin{array}{l}18.5 \\
\mathrm{~h}\end{array}$ \\
\hline $\mathbf{1}$ & 6.62 & 6.70 & 6.70 & 6.72 & 6.78 \\
\hline $\mathbf{2}$ & 7.05 & 7.08 & 7.07 & 7.08 & 7.10 \\
\hline $\mathbf{5}$ & 3.75 & 3.64 & 3.63 & 3.65 & 3.69 \\
\hline $\mathbf{6}$ & 3.85 & 3.83 & 3.84 & 3.84 & 3.84 \\
\hline $\mathbf{H}_{2} \mathbf{O}$ & - & 7.77 & 8.60 & 9.25 & 10.50 \\
\hline
\end{tabular}

Table S1. Time dependent shifts (ppm) for selected nuclei after addition of $\mathrm{NaPF}_{6}$. 